Reprinted from: Weed Science. 1998. 46(5):510-513.

Published by: Weed Science Society of America. http://www.wssa.net/

\title{
AC 263,222 absorption and fate in leafy spurge (Euphorbia esula)
}

\author{
W. MACK THOMPSON, SCOTT J. NISSEN, and ROBERT A. MASTERS \\ Department of Bioagricultural Sciences and Pest Management, Colorado State University, Fort Collins, CO 80523, \\ Corresponding author, Department of Bioagricultural Sciences and Pest Management, Colorado State University, Fort \\ Collins, CO 80523; snissen@lamar.colostate.edu, and U.S. Department of Agriculture, Agriculture Research Service, \\ Department of Agronomy, University of Nebraska, Lincoln, NE 68583-0915
}

\begin{abstract}
:
Absorption, translocation, and metabolism of AC 263,222 by leafy spurge were studied over 8 days. Based on the amount of herbicide applied and recovered from the leaf surfaces, 40\% of applied AC 263,222 was absorbed by leafy spurge 2 days after treatment (DAT), with no further absorption observed by 8 DAT. Eight DAT $19 \%$ of applied $\left[{ }^{14} \mathrm{C}\right]-\mathrm{AC}$ 263,222 had translocated to below-ground plant parts while $4 \%$ was exuded from the roots into the sand media. AC 263,222 was not metabolized 2 DAT in the crown, root, and root buds, but $42 \%$ was metabolized in the treated leaves. Only $17 \%$ of recovered $\left[{ }^{14} \mathrm{C}\right]$ was AC 263,222 in treated leaves 8 DAT (83\% metabolized), while AC 263,222 accounted for 70\% of recovered $\left[{ }^{14} \mathrm{C}\right]$ in the root and root buds. HPLC analysis indicated that the balance of $\left[{ }^{14} \mathrm{C}\right]$ was associated with a single, polar metabolite. Total recovery of $\left[{ }^{14} \mathrm{C}\right]$ was $88 \%$ at $8 \mathrm{DAT}$.
\end{abstract}

\section{Nomenclature:}

AC 263,222; ammonium nitrate, $\mathrm{NH}_{4} \mathrm{NO}_{3}$; leafy spurge, Euphorbia esula L. EPHES.

\section{Keywords:}

Translocation, metabolism, root exudation, rangeland weed, imidazolinone, perennial weed, adventitious shoot buds, EPHES. 


\section{Introduction}

The noxious, perennial weed leafy spurge was introduced into the central United States from Eurasia in the late 1800s and, by 1979, infested nearly one million ha in the northern and central Great Plains and Prairie Provinces of Canada (Dunn 1985). Leafy spurge is a threat to these areas because it displaces native species and competes with desirable forage, ultimately reducing plant diversity and diminishing rangeland carrying capacity (Masters 1990). The aggressive, competitive nature of leafy spurge is due in part to prolific vegetative reproduction from adventitious shoot buds located on crowns and roots (Coupland et al. 1955). Its extensive root system and abundant carbohydrate reserves allows the plant to survive many mechanical and chemical control measures. To be successful, leafy spurge management strategies must reduce seed production and inhibit regrowth from adventitious shoot buds.

Herbicides currently provide the most effective means to manage established leafy spurge infestations (Masters 1990). Commonly recommended treatments include annual applications of 2,4-D at $1.1 \mathrm{~kg}$ ae ha ${ }^{-1}$ in combination with picloram at 0.28 to $0.56 \mathrm{~kg}$ ae $\mathrm{ha}^{-1}$. These treatments reduce leafy spurge seed production and can increase forage yield (Lym and Messersmith 1985) but do not provide long-term control and suppress desirable broadleaf forages. Picloram at $2.2 \mathrm{~kg} \mathrm{ha}^{-1}$ can reduce the size of existing infestations and extend the duration of leafy spurge suppression, but high cost limits the use of this treatment. The imidazolinone herbicides imazapyr, imazethapyr, imazaquin, and AC 263,222 are phytotoxic to leafy spurge (Masters et al. 1994, 1997; Stougaard et al. 1994). Certain forage grasses tolerate imazethapyr, imazaquin, and AC 263,222 (Masters et al. 1994; Stougaard et al. 1994), and these herbicides facilitate establishment of native tall grasses and selected forbs (Masters et al. 1996).

To control perennial weeds, such as leafy spurge, herbicides must translocate in phytotoxic amounts and must resist metabolic detoxification by the plant. The behavior of imazapyr and imazethapyr in leafy spurge has been characterized (Nissen et al. 1994, 1995). Compared to picloram and 2,4-D, higher percentages of imazapyr and imazethapyr are absorbed through the leaves and translocated to the root system and adventitious shoot buds. In addition, imazapyr and imazethapyr are not readily metabolized by leafy spurge to nonphytotoxic metabolites. AC 263,222 is very similar in structure and activity to imazapyr and imazethapyr but is more selective than imazapyr and provides better control of leafy spurge than imazethapyr (Masters et al. 1994, 1996, 1997). The objectives of this study were to determine absorption, translocation, and metabolism of AC 263,222 in leafy spurge.

\section{Materials and methods}

\section{Plant material}

Root cuttings from a single plant collected near Bozeman, MT, were used to generate a population of genetically uniform plants by vegetative propagation. Cuttings were 
planted into $4 \mathrm{~cm}$. diameter by $20 \mathrm{~cm}$ long cones ${ }^{1}$ and grown in a greenhouse for at least 3 mo. Natural light was supplemented with metal halide lamps that provided an additional $300 \mu \mathrm{mol} \mathrm{m} \mathrm{m}^{-2} \mathrm{~s}^{-1}$ photosynthetic photon flux (PPF). Plants were fertilized weekly with the equivalent of $200 \mathrm{mg} \mathrm{L}^{-1}$ nitrogen using 20-19-18 (N-P-K) with minor nutrients.

For all subsequent experiments, the development of uniform shoot growth was achieved by removing shoot growth from plants grown in the greenhouse and placing root systems in cold storage at $4^{\circ} \mathrm{C}$ for 14 days. This process increases the vigor of shoot growth from adventitious shoot buds on leafy spurge crowns (Harvey and Nowierski 1988). Following cold treatment, root systems were transplanted into $8 \mathrm{~cm}$ diameter by $30 \mathrm{~cm}$ long cones filled with fine, washed silica sand and placed in a growth chamber. Growth chamber conditions were: 16 hour photoperiod, $25 / 20^{\circ} \mathrm{C}$ day/night temperature, $50 \%$ relative humidity, and PPF of $500 \mu \mathrm{mol} \mathrm{m} \mathrm{m}^{-2} \mathrm{~s}^{-1}$. Plants were watered daily $(25 \mathrm{ml})$ and fertilized when transplanted and at 14 days with $0.6 \mathrm{~g}$ per pot of slow release fertilizer $^{2}$.

\section{Absorption, Translocation, and Root Release}

Experiments were conducted using $26 \mathrm{~cm}$ tall, single stem plants in midbloom growth stage, approximately 18 to 24 days after being transferred to the growth chamber. AC 263,222 was applied at $0.07 \mathrm{~kg} \mathrm{ha}^{-1}$ in water with $1.25 \%(\mathrm{v} / \mathrm{v})$ methylated seed oil and $1.25 \%(\mathrm{v} / \mathrm{v}) 28 \%$ urea ammonium nitrate (UAN). Herbicide applications were made using an overhead track sprayer calibrated to deliver $187 \mathrm{~L} \mathrm{ha}^{-1}$. At the time of herbicide application, two alternate leaves, approximately $10 \mathrm{~cm}$ below the shoot apex, were protected from the spray solution with aluminum foil. $\left[{ }^{14} \mathrm{C}\right]-\mathrm{AC} 263,222$ (specific activity $821 \mathrm{kBq} \mathrm{mg}^{-1}$ ) was mixed with spray solution and applied to the protected leaves as 20 , $0.5 \mu \mathrm{l}$ droplets $(5 \mu \mathrm{l}$ per leaf, $17 \mathrm{kBq}$ per plant). Following treatment, the plants were immediately returned to the growth chamber.

Plants were harvested 2 and 8 DAT. Treated leaves were removed and vortexed for $30 \mathrm{~s}$ in $5 \mathrm{ml} 10 \%$ aqueous methanol containing $0.25 \%$ nonionic surfactant. Radioactivity in the leaf wash solution was determined by liquid scintillation spectroscopy (LSS) and used to estimate herbicide absorption. Plants were then divided into seven parts: shoot above treated leaves, treated leaves, shoot below treated leaves, crown, root, dormant adventitious shoot buds, and elongated adventitious shoot buds. Treated leaves, crown, root, and adventitious shoot buds (dormant and elongated) were immediately frozen in liquid $\mathrm{N} 2$ and stored at $-20^{\circ} \mathrm{C}$ for metabolite analysis. Shoot material was oven dried at $55^{\circ} \mathrm{C}$ for 72 hours. Dried plant material was weighed and ground to a fine powder in liquid $\mathrm{N}_{2}$ with a mortar and pestle and the amount of ${ }^{14} \mathrm{C}$ was determined by sample oxidation ${ }^{3}$ followed by LSS. The silica-sand rooting media was rinsed from the roots with $1 \mathrm{~L}$ of water into a 12-cm.-diam-büchner funnel containing Whatman \#1 filter paper. The water was pulled through the sand under vacuum. Subsamples $(7 \mathrm{ml})$ of the filtrate were removed and

\footnotetext{
${ }^{11}$ Stuewe and Sons, Inc., Corvallis, OR 97333.

${ }^{2}$ Sierra, 17-6-10 N-P-K, Grace-Sierra Horticultural Products Co., Milpitas, CA 95035.

${ }^{3}$ OX-500 Biological Oxidizer, R.J. Harvey Instrument Corp., Hillsdale, NJ 07642.
} 
amount of ${ }^{14} \mathrm{C}$ was determined by LSS. Remaining ${ }^{14} \mathrm{C}$ located in the other plant parts was determined by high-performance liquid chromatography (HPLC).

\section{Metabolism}

AC 263,222 and metabolites were extracted from the plant parts by grinding samples in $10 \mathrm{ml} 90 \%$ aqueous methanol using a tissue homogenizer ${ }^{4}$. Tissue samples were shaken for 2 hours followed by filtration through $0.2-\mu \mathrm{m}$ membranes ${ }^{5}$. The particulate was oxidized and counted by LSS to verify ${ }^{14} \mathrm{C}$ extraction. The filtrate was reduced to $400 \mu \mathrm{l}$ under vacuum and $100 \mu \mathrm{l}$ subsamples were fractionated by reversed-phase HPLC 6 coupled with in-line ${ }^{14} \mathrm{C}$ detection ${ }^{7}$. The solvents were HPLC-grade water acidified with $0.1 \%$ phosphoric acid and HPLC-grade acetonitrile used in a three-step binary gradient (Neighbors and Priville 1990). The percent $\left[{ }^{14} \mathrm{C}\right]-\mathrm{AC} 263,222$ remaining was determined by the ratio of the AC 263,222 peak to the total ${ }^{14} \mathrm{C}$ of the extract.

Table 1. Absorption and distribution of ${ }^{14} \mathrm{C}$ in leafy spurge 2 and 8 DAT with ${ }^{14} \mathrm{C}$-AC 263,222.

\begin{tabular}{|c|c|c|}
\hline \multirow[b]{2}{*}{ Section } & \multicolumn{2}{|c|}{ Absorption and distribution of ${ }^{14} \mathrm{C}$} \\
\hline & $2 \mathrm{DAT}$ & $8 \mathrm{DAT}$ \\
\hline & \multicolumn{2}{|c|}{$\%$ of applied } \\
\hline Total absorption ${ }^{\mathrm{a}}$ & 40.5 & 43.7 \\
\hline Treated leaves & 8.7 & 5.7 \\
\hline Shoot above treated leaves & 4.1 & 3.9 \\
\hline Shoot below treated leaves & 4.5 & 2.6 \\
\hline Crown & 2.8 & 2.4 \\
\hline Root & 10.2 & 9.0 \\
\hline Dormant adventitious shoot buds & 2.2 & 2.7 \\
\hline Elongating adventitious shoot buds & 0.8 & 0.9 \\
\hline Sand wash & 3.3 & 4.2 \\
\hline $\operatorname{LSD}(0.05)$ & 3.3 & \\
\hline Recovered ${ }^{14} \mathrm{C}$ & 96.1 & 87.7 \\
\hline
\end{tabular}

${ }^{\mathrm{a} C}$ Calculated as amount applied minus leaf wash.

\footnotetext{
${ }^{4}$ Tempest Homogenizer, Virtis Company, Gardiner, NY 12525.

${ }^{5}$ Nylaflo, Gelman Sciences, Ann Arbor, MI 48106.

${ }^{6}$ Hitachi Instruments, Inc., San Jose, CA 95134.

${ }^{7}$ P-RAM, INUS Systems, Inc., Tampa, FL 33610.
} 


\section{Data analyses}

Experiments were designed as factorials with plant part and days after treatment (DAT) as factors. Treatments were replicated six times and experiments were repeated. Percentage data from absorption, translocation, and metabolism experiments were arcsine transformed and $\mathrm{Bq} \mathrm{g}^{-1}$ dry wt data from root and adventitious buds were $\log$ transformed before statistical analyses. These transformations did not change the results of the statistical analyses and nontransformed data are presented. Bartlett's test for homogeneity of variance indicated that the variances from the two experiments were similar and that the data could be combined. Mean values for parameters measured were compared using Fisher's protected least significant difference $(\mathrm{P}=0.05)$ (Steel and Torrie 1980).

\section{Results and discussion}

\section{Absorption, translocation, and root release}

Recovery of applied ${ }^{14} \mathrm{C}$ was $96 \% 2$ DAT and $88 \% 8$ DAT. Forty percent of applied $\left[{ }^{14} \mathrm{C}\right]$-AC 263,222 was absorbed into the plant 2 DAT with no significant increase in absorption through 8 DAT (Table 1). AC 263,222 absorption by leafy spurge was greater than that reported for picloram. (14\%) (Lym and Moxness 1989; Moxness and Lym 1989; Thompson et al. 1996) and quinclorac (0\% without lutensol) (Lamoureux and Rusness 1995), similar to that reported for 2,4-D (34 to 78\%) (Lym and Moxness 1989; Thompson et al. 1996) and fluroxypyr (48\%) (Lym 1992) absorption, but less than that reported for imazapyr (80\%) (Nissen et al. 1995) and glyphosate (81\%) (Maxwell et al. 1987). Imazethapyr absorption by leafy spurge ranged from 20 to $80 \%$ and was dependent on the use adjuvants, especially UAN and ammonium sulfate (AS) (Thompson et al. 1996). Newsom et al. (1995) reported less AC 263,222 absorption by soybean $(<10 \%)$ [Glycine $\max (\mathrm{L}$.$) Merr.] than leafy spurge; however, no nitrogen was used in the soy-$ bean treatment solutions.

Table 2. Concentration of ${ }^{14} \mathrm{C}$ in roots and adventitious shoot buds of leafy spurge 2 and 8 DAT with ${ }^{14} \mathrm{C}$-AC 263,222.

\begin{tabular}{lcc}
\hline & \multicolumn{2}{c}{ Concentration of ${ }^{14} \mathrm{C}$} \\
\cline { 2 - 3 } Plant section & $2 \mathrm{DAT}^{\mathrm{a}}$ & $8 \mathrm{DAT}$ \\
\hline \multirow{2}{*}{ Root } & $200 \mathrm{a}$ & $254 \mathrm{ab}$ \\
Dormant adventitious shoot buds & $652 \mathrm{c}$ & $670 \mathrm{c}$ \\
Elongating adventitious shoot buds & $486 \mathrm{bc}$ & $704 \mathrm{c}$ \\
\hline
\end{tabular}

${ }^{\mathrm{a}}$ Means followed by the same letter are not significantly different at $\mathrm{P}=0.05$. 
AC 263,222 appears to be very mobile in leafy spurge. Sixteen percent of applied ${ }^{14} \mathrm{C}$ $\left(40 \%\right.$ of absorbed ${ }^{14} \mathrm{C}$ ) was recovered from the belowground plant parts (crown, root, and adventitious shoot buds) 2 DAT (Table 1). The amount of AC 263,222 translocating to the crown and root tissue did not increase from 2 to 8 DAT and was similar to that reported for imazapyr (Nissen et al 1995). Less than 5\% of applied $\left[{ }^{14} \mathrm{C}\right]$-picloram (Lym and Messersmith 1990; Lym and Moxness 1989; Moxness and Lym 1989), $\left[{ }^{14} \mathrm{C}\right]-2,4-\mathrm{D}$ (Lym 1992; Lym and Moxness 1989), [ $\left.{ }^{14} \mathrm{C}\right]$-fluroxypyr (Lym 1992), and $\left[{ }^{14} \mathrm{C}\right]-$ imazethapyr (Nissen et al. 1994) translocated to leafy spurge roots, compared to translocation of $>15 \%$ of applied $\left[{ }^{14} \mathrm{C}\right]$-AC 263,222 (Table 1) and $\left[{ }^{14} \mathrm{C}\right]$-imazapyr (Nissen et al. 1995).

Loss of AC 263,222 from leafy spurge through root release or exudation was similar to that reported for imazethapyr (Nissen et al. 1994) and imazapyr (Nissen et al. 1995) (Table 1). Filtrate of the rooting media contained 3.3 and $4.2 \%$ of the applied $\left[{ }^{14} \mathrm{C}\right]-\mathrm{AC}$ 263,222, 2 and 8 DAT, respectively; therefore, leafy spurge released 17 to $22 \%$ of the $\left[{ }^{14} \mathrm{C}\right]$-AC 263,222 that translocated to the crown and root system. Previous studies indicated that leafy spurge roots released 10 and 19\% of imazethapyr and imazapyr translocating to the root system (Nissen et al. 1994, 1995), while 60 to $80 \%$ of picloram and 2,4D were released from leafy spurge roots (Hickman et al. 1989; Lym and Moxness 1989).

Although seed production is important in reproduction and dispersion of leafy spurge, established stands reproduce primarily from adventitious shoot buds. An herbicide must translocate to adventitious shoot buds of leafy spurge in phytotoxic quantities to provide long-term control. Nissen et al. $(1994,1995)$ found that imazethapyr and imazapyr preferentially translocate to adventitious shoot buds of leafy spurge versus root tissue. In the current study, only $3 \%$ of applied $\left[{ }^{14} \mathrm{C}\right]$-AC 263,222 was recovered from the adventitious shoot buds 2 DAT compared to $10 \%$ from root tissue (Table 1); however, the average dry weight of the roots is 10 times that of adventitious shoot buds $(1,400 \mathrm{mg}$ vs. $110 \mathrm{mg})$. Comparisons based on $\mathrm{Bq} \mathrm{g}^{-1}$ dry weight indicate that two- to threefold more $\left[{ }^{14} \mathrm{C}\right]-\mathrm{AC}$ 263,222 accumulated in the adventitious shoot buds compared to root tissue (Table 2). Partitioning of AC 263,222 into the adventitious shoot buds may contribute to the high level of leafy spurge control observed in the field by Masters et al. (1997).

\section{Metabolism}

The majority of ${ }^{14} \mathrm{C}$ that translocated to the belowground plant parts remained as intact AC 263,222 (Table 3). Greater than $70 \%$ of the ${ }^{14} \mathrm{C}$ recovered from the root, crown, and adventitious shoot bud tissue 8 DAT was parent AC 263,222; however, only $17 \%$ of AC 263,222 remained intact in the leaves. The rate of metabolism of AC 263,222 metabolism in leafy spurge appears intermediate between imazapyr and imazethapyr. Few plants, including leafy spurge, can metabolize imazapyr (Little et al. 1994). Leafy spurge roots and adventitious shoot buds metabolized less than $1 \%$ of imazapyr 8 DAT (Nissen et al. 1995) but metabolized approximately $45 \%$ of imazethapyr (Nissen et al. 1994). 
Table 3. Metabolism of ${ }^{14} \mathrm{C}$-AC 263,222 in leafy spurge 2 and 8 DAT.

\begin{tabular}{lcc}
\hline \multirow{2}{*}{ Plant section } & ${ }^{14} \mathrm{C}$ remaining as intact AC 263,222 \\
\cline { 2 - 3 } Treated leaves & 2 DAT & 8 DAT \\
Crown & 58 & 17 \\
Root & 92 & 72 \\
Dormant adventitious shoot buds & 96 & 68 \\
Elongating adventitious shoot buds & 96 & 69 \\
LSD $(0.05)$ & 93 & 81 \\
\hline
\end{tabular}

Herbicide metabolism often results in a more polar molecule. This change in the physicochemical properties of the herbicide reduces the molecule's membrane solubility and influences its phloem mobility (Devine 1989). There is differential metabolism of AC 263,222 in the treated leaf and that transported to other plant parts (Table 3). While there is no significant increase in translocation between 2 and 8 DAT, metabolism of AC 263,222 substantially increases in the treated leaf during this time. These findings suggest that metabolized AC 263,222 is not transported out of the leaf.

AC 263,222 had a retention time of 23.5 minutes and was preceded by a major metabolite peak at 19.5 minutes (Figure 1). These two peaks accounted for $>80 \%$ of the total radioactivity. Although specific metabolites were not identified, it is suspected that the polar metabolite was a hydroxylated product $\left(5-\mathrm{CH}_{2} \mathrm{OH}\right)$ (Little et al. 1994). Leafy spurge rapidly metabolizes imazethapyr to its primary metabolite 5hydroxyethyl-imazethapyr (Nissen et al. 1994), which remains phytotoxic (Shaner 1991). Tolerant species such as soybean and peanut (Arachis hypogaea L.) detoxify 5hydroxyethyl imazethapyr by conjugation to glucose (Shaner and Mallipudi 1991; Tecle et al. 1993). Similar metabolism may occur with

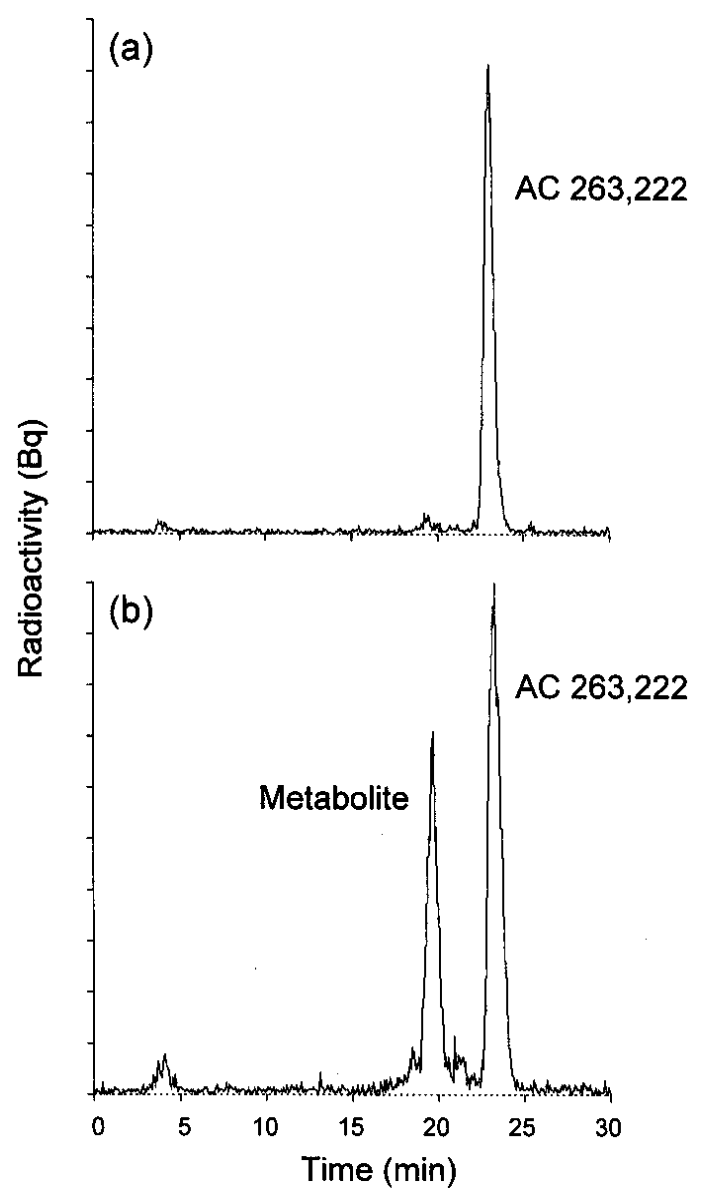

Figure 1. High-performance liquid chromatograms of ${ }^{14} \mathrm{C}$-AC 263,222 (a) standard and (b) in root tissue 8 DAT. 
AC 263,222. The hydroxylated metabolite appears to be phytotoxic (Little et al. 1994); therefore, an additional metabolic step is probably required to detoxify AC 263,222.

There is some evidence that 5-hydroxyethyl imazethapyr is sequestered within cells (Barrett 1989; Shaner and Mallipudi 1991); however, this was not evident for the hydroxylated metabolite of AC 263,222 when absorbed by and transported from the roots of corn (Zea mays L.) and sunflower (Helianthus annuus L.) (Little et al. 1994). Sequestration of 5-hydroxyethyl imazethapyr may explain why less $\left[{ }^{14} \mathrm{C}\right]$ translocated to leafy spurge roots when treated with imazethapyr compared to imazapyr and AC 263,222.

AC 263,222 has several characteristics that contribute to leafy spurge control. It is readily absorbed by leafy spurge and preferentially translocates to the primary perennating organs, adventitious shoot buds. Leafy spurge slowly metabolizes AC 263,222 in roots and adventitious shoot buds and may lack the ability to completely detoxify the herbicide. AC 263,222 absorption, translocation, and metabolism data support the high level of leafy spurge control observed in the field.

\section{Acknowledgments}

The authors thank American Cyanamid for financial support of this research and also for supplying radiolabeled AC 263,222. Sincere thanks goes to Todd Graus and Paula Cutillo for their efforts in the laboratory. Journal Ser. No. 12300, Agricultural Research Division, University of Nebraska, Lincoln.

\section{Literature cited}

1. Barrett, M. 1989. Reduction of imazaquin injury to corn (Zea mays) and sorghum (Sorghum bicolor) with antidotes. Weed Sci. 37:34-41.

2. Coupland, R. T., G. W. Selleck, and J. F. Alex. 1955. Distribution of vegetative buds on the underground parts of leafy spurge (Euphorbia esula L.). Can. J. Agric. Sci. 35:76-82.

3. Devine, M. D. 1989. Phloem translocation of herbicides. Rev. Weed Sci. 4:191-213.

4. Dunn, P. H. 1985. Origins of leafy spurge in North America. Pages 7-13 in A. K. Watson, ed. Leafy Spurge. Champaign, IL: Weed Science Society of America.

5. Harvey, S. J. and R. M. Nowierski. 1988. Release of postsenescent dormancy in leafy spurge (Euphorbia esula) by chilling. Weed Sci. 36:784-786.

6. Hickman, M. V., C. G. Messersmith, and R. G. Lym. 1989. Picloram release from leafy spurge (Euphorbia esula) roots in the field. Weed Sci. 37:167-174.

7. Lamoureux, G. L. and D. G. Rusness. 1995. Quinclorac absorption, translocation, metabolism and toxicity in leafy spurge (Euphorbia esula). Pestic. Biochem. Physiol. 53:210-226.

8. Little, D. L., D. L. Shaner, D. W Ladner, and B. Tecle. 1994. Root absorption and translocation of 5substituted analogs of the imidazolinone herbicide, imazapyr. Pestic. Sci. 41:161-169.

9. Lym, R. G. 1992. Fluroxypyr absorption and translocation in leafy spurge (Euphorbia esula). Weed Sci. 40:101-105.

10. Lym, R. G. and C. G. Messersmith. 1985. Leafy spurge control and improved forage production with herbicides. J. Range Manage. 38:386-391.

Page 8 of 9 
11. Lym, R. G. and C. G. Messersmith. 1990. Effect of temperature on picloram absorption and translocation in leafy spurge (Euphorbia esula). Weed Sci. 38:471-474.

12. Lym, R. G. and K. D. Moxness. 1989. Absorption, translocation, and metabolism of picloram. and 2,4-D in leafy spurge (Euphorbia esula). Weed Sci. 37:498-502.

13. Masters, R. A. 1990. Leafy spurge: threat to central plains grasslands. Pages 101-106 in Proceedings of the Twelfth North American Prairie Conference. Cedar Falls, IA: University of Northern Iowa. '

14. Masters, R. A., R. N. Stougaard, and S. J. Nissen. 1994. Leafy spurge (Euphorbia esula) control with fall-applied imazapyr, imazaquin, and imazethapyr. Weed Technol. 8:58-63.

15. Masters, R. A., S. J. Nissen, R. E. Gaussoin, D. D. Beran, and R. N. Stougaard. 1996. Imidazolinone herbicides improve restoration of Great Plains grasslands. Weed Technol. 10:392-403.

16. Masters, R. A., E. Rivas-Pantoja, and D. Beran. 1997. Response of leafy spurge (Euphorbia esula L.) and associated vegetation to AC 263,222. Page 31 in Proceedings of the Weed Science Society of America, D. S. Murray, ed. Orlando, FL: Weed Science Society of America.

17. Maxwell, B. D., M. E. Foley, and P. K. Fay. 1987. The influence of glyphosate on bud dormancy in leafy spurge (Euphorbia esula). Weed Sci. 35:6-10.

18. Moxness, K. D. and R. G. Lym. 1989. Environment and spray additive effects on picloram absorption and translocation in leafy spurge (Euphorbia esula). Weed Sci. 37:181-186.

19. Neighbors, S. and L. S. Priville. 1990. Metabolism of primisulfuron by barnyard grass. Pestic. Biochem. Physiol. 37:145-153.

20. Newsom, L. J., D. R. Shaw, and T. E. Hubbard, Jr. 1995. Absorption, translocation, and metabolism of AC 263,222 in selected soybean (Glycine max) cultivars. Weed Sci. 43:536-540.

21. Nissen, S. J., R. A. Masters, and R. N. Stougaard. 1994. Imazethapyr absorption and fate in leafy spurge (Euphorbia esula). Weed Sci. 42:158-162.

22. Nissen, S. J., R. A. Masters, W M. Thompson, and R. N. Stougaard. 1995. Absorption and fate of imazapyr in leafy spurge (Euphorbia esula L.) Pestic. Sci. 45:325-329.

23. Shaner, D. L. 1991. Mode of action of naphthalic acid as a safener for imazethapyr. Z. Naturforsch. 46:893-896.

24. Shaner, D. L. and N. H. Mallipudi. 1991. Mechanisms of selectivity of the imidazolinones. Pages 91102 in D. L. Shaner and S. I. O’Connor, eds. The Imidazolinone Herbicides. Boca Raton, FL: CRC Press.

25. Steel, R. G. D. and J. H. Torrie. 1980. Principles and procedures of statistics. A biometrical approach. New York: McGraw-Hill. 633 p.

26. Stougaard, R. N., R. A. Masters, and S. J. Nissen. 1994. Leafy spurge (Euphorbia esula) control with imidazolinone and sulfonylurea herbicides. Weed Technol. 8:494-498.

27. Tecle B., A. Da Cunha, and D. L. Shaner. 1993. Differential routes of metabolism of imidazolinones: basis for soybean (Glycine max) selectivity. Pestic. Biochem. Physiol. 46:120-130.

28. Thompson, W. M., S. J. Nissen, and R. A. Masters. 1996. Adjuvant effects on imazethapyr, 2,4-D and picloram absorption by leafy spurge (Euphorbia esula). Weed Sci. 44:469-475. 